\title{
Consummate Love Pada Pasutri Dengan Istri Mantan Pekerja Seks Komersial
}

\author{
Ilva Mardhotin Izzy', Masrifah ${ }^{2}$ \\ ${ }^{1}$ Program Studi Psikologi, Jurusan Ilmu Sosial dan Ilmu Budaya \\ Fakultas Ilmu Sosial dan Ilmu Budaya \\ Universitas Trunojoyo Madura \\ masrifah@trunojoyo.co.id
}

\begin{abstract}
Consumatte love or as known as a perfect love is a love that happens from intimacy, passion and commitment. The most interesting part to discuss is an ex prostitute who gets married to a man using consumatte love/perfect love approach.

In this study, researcher is using a married couple as her subject's research. There are criterias in order to choose this research. First is, the researcher choose a married woman who has been an ex prostitute, that married couple should have been in 10 years relationship or still counting, have no kids who works as a breadwinner for the family and they live their happy life. This study aims to determine the perfect love (Consummate Love) of an ex prostitute who gets married and being a wife. This research is using qualitative approach and an explanatory techniques with a single case. Respondents in this study were 2 women and 2 men who were a married couple.The analysis technique's branch that used is a structured explanation technique. The results of this study indicate the motive behind the reason why this women stop being a prostitute and being a good wives to do a household that ther are dreaming about. Positive encouragement or motivation given by the husband to strenghten thier wives in order to socialize with the society around. Wives need to accept any situation that occurs in their household, such as patient and sincere deals with household problems, does not require thier husband to fulfill their desires and needs. There are Many other factors which influence the reason behind the process of stop being a prostitute and be a wives to do a household and it describes in chapter 4.
\end{abstract}

Keywords: Case study, Consumatte love, A married couple, An ex prostitute

\begin{abstract}
Abstrak
Consummate Love (cinta yang sempurna), yaitu cinta yang tersusun atas komponen keintiman, gairah dan komitmen. Pasangan suami istri dengan masalalu istri sebagai pekerja seks komersial memiliki perjalanan rumah tangga yang menarik untuk dibahas dengan menggunakan cinta sempurna atau consummate love sebagai landasan utamanya.

Pasutri dalam subjek peneltian ini memiliki kriteria diantaranya istri memiliki masalalu wanita pekerja seks komersial, pernikahan yang sudah berjalan 10 tahun atau lebih, tidak memiliki anak (keturunan), istri yang bekerja sebagai
\end{abstract}


pencari nafkah utama dalam rumah tangga dan keadaan rumah tangga yang bisa menggambarkan keadaan harmonis. Penelitian ini bertujuan untuk mengetahui gambaran cinta sempurna (Consummate Love) pada pasutri dengan istri mantan pekerja seks komersial. Peneliti pada penelitian ini menggunakan pendekatan kualitatif yang berjenis studi kasus dengan menggunakan teknik eksplanatori dengan kasus tunggal. Responden dalam penelitian ini merupakan 2 wanita dan 2 laki-laki yang merupakan sepasang suami istri. Teknik analisis yang digunakan teknik eksplanasi terstruktur. Hasil dari penelitian ini menunjukkan bahwa tujuan awal dirinya berhenti menjadi PSK yaitu untuk menjalankan dengan baik kehidupan pernikahan yang diimpikannya dan menerima keadaan rumah tangga yang akan dialami. Dorongan positif atau motivasi diberikan oleh pihak suami menjadikannya kekuatan untuk bisa melewati berbagai macam reaksi sosial masyarakat, menerima keadaan apapun yang terjadi pada rumah tangganya, Sabar dan ikhlas dalam menghadapi masalah rumah tangga, tidak menuntut sesama pasangan untuk memenuhi keinginan dan kebutuhannya. Banyak juga faktor pendorong lain mempengaruhinya, pada bab 4 telah dijelaskan dalam bentuk deskripsi dan tabel hasil tema yang muncul dari wawancara kedua pasutri tersebut.

Kata Kunci : Studi kasus, Consummate Love, Pasutri, Istri Mantan Pekerja Seks Komersial

\section{Pendahuluan}

Pemilihan pasangan merujuk pada proses dimana individu mencari teman untuk dilibatkan dalam sebuah hubungan. Bahwa ketika terjadi pemilihan pasangan, hal ini merupakan sebuah proses di antara dua individu yang dimulai dengan ketertarikan awal yang menjadi perkenalan biasa saja, lalu beralih ke arah kencan serius dan menjadi komitmen jangka panjang yang berakhir pada pernikahan. Pemilihan pasangan adalah proses mencari dan menemukan teman untuk dilibatkan dalam hubungan yang kemudian menjadikan hubungan sebagai komitmen jangka panjang dan berakhir pada pernikahan, (Wisnuwardhani, 2011). Setelah berhasil saling menyesuaikan diri, tahapan selanjutnya tentu saja meningkatkan komitmen yang lebih dalam hubungan mereka dengan proses pertunangan dengan pasangan yang sudah dipilih individu. Jika individu dan pasangannya berhasil menjalani proses dengan baik, maka mereka dapat menikah atau mengembangkan hubungan yang mengarah pada pernikahan, (Kerkchoff \& Davis.- dalam Wisnuwardhani, 2011).

Menurut hasil penelitian yang dilakukan oleh Febriani, (2010) di Indonesia 
ditemukan fakta bahwa terdapat kemunduran usia pernikahan pada pria dan wanita dewasa. Peneliti berasumsi bahwa individu yang memiliki keyakinan mengenai pasangan hidup ideal yang terlalu kuat dapat menghambat seseorang dalam mendapatkan pasangannya. Keyakinan pemilihan pasangan hidup yang ideal dapat terbentuk melalui pengalaman pribadi. Terdapat tujuh dimensi yang mendasari keyakinan tersebut yaitu, individu hanya akan menikah dengan seseorang yang akan menjadi pasangannya, cinta merupakan satu syarat yang cukup untuk menikah, tinggal bersama sebelum menikah dan melakukan kontak fisik sebelum menikah, individu hanya akan menikah jika semua kriteria terpenuhi, menikah dengan pasangan yang berbeda karakter akan membuat hubungan menjadi saling melengkapi, individu menikah jika dirinya merasa sempurna dan kualitas hubungan sesuai dengan yang diinginkan, serta berusaha dengan keras untuk mendapatkan pasangan hidup.

Konsep pemilihan pasangan yang ditinjau dari konsep bibit, bebet, dan bobot tidak hanya diberlakukan pada etnis/suku jawa saja, namun disetiap etnis/suku di Indonesia memiliki konsep tersebut dengan istilah yang berbeda.

Fenomena yang ada saat ini di masyarakat, masih banyak orang tua yang berpatokan pada nilai dan norma adat ketika akan memilih calon pasangan untuk anaknya. Banyak faktor sosio-kultural yang berpengaruh dalam pemilihan calon pasangan hidup selain usia pasangan, pendidikan, etnis dan profesi (Norma, 1990). Menurut Saraswati (2011), kriteria status sosial maupun ekonomi sebagai salah satu bagian dari tolak ukur bibit, bebet, dan bobot ini kemudian menjadi syarat bagi orang tua sebelum menikahkan anaknya. Agar harapan orang tua dapat tercapai maka orang tua menyampaikan syarat atau kriteria tertentu kepada anaknya.

Dalam penelitian Matondang (2014) Faktor ekonomi, yang menyebabkan sering timbul pertengkaran di rumah tangga. Masalah ekonomi adalah masalah yang kompleks pada saat sekarang ini, karena kebutuhan terus meningkat dan penghasilan sedikit, sedangkan penghasilan hanya pas-pasan; sering menjadi pemicu perceraian dalam rumah tangga. Faktor belum memiliki keturunan. Salah satu penyebab terjadinya perceraian di Desa Harapan karena pasangan suami istri belum memiliki keturunan. Memiliki keturunan merupakan dambaan setiap 
pasangan suami istri, karena rumah tangga serasa sudah lengkap dengan hadirnya anak.

Penelitian serupa juga dilakukan Toha dan Arifin (2018), Realitas di masyarakat terjadi peningkatan jumlah angka perceraian di Sampang dan Pamekasan dalam kurun waktu 3 tahun terakhir. Tidak terpenuhinya kebutuhan nafkah lahir (ekonomi), tidak adanya komunikasi yang berkualitas antara suamiistri, tidak ada saling pengertian dan saling mengalah, tidak adanya pemahaman akan hak dan kewajiban, tugas dan tanggung jawab suami-istri, dan sebagainya akan menjadikan keluarga dalam rumah tangga selalu bertengkar dan berselisih yang mengakibatkan perceraian.

Berdasarkan hasil wawancara dengan informan SM, mengatakan:

"Saya menikah dengan suami saya sudah 15 tahun hingga saat ini, awalnya suami saya bekerja sebagai tukang becak (transportasi umum) dengan penghasilan paspasan menurut saya pada saat itu, hingga saat ini penghasilan suami saya semakin berkurang karena dia (suami) memutuskan berhenti menjadi tukang becak dan tidak bekerja. Pekerjaannya sekarang hanya berternak burung love bird itupun harga love bird sekarang hancur (turun) di pasaran sangat murah, suami saya kemarin sempat merugi banyak. Sekarang yang bekerja hanya saya saja sebagai buruh cuci kadang juga saya sering disuruh orang tetangga sekitar untuk membantu mencuci piring dan memasak jika ada hajatan di rumahnya). (Wawancara dengan SM, 45 tahun, tanggal 16 februari 2020).

Hasil wawancara tersebut dapat disimpulkan bahwa informan SM tetap bertahan dalam keadaan ekonomi yang rendah dengan suaminya, dan tidak menuntut kepada suami untuk memenuhi kebutuhan ekonomi keluarga, informan SM saat ini juga membantu memenuhi ekonomi keluarga dengan tidak menyalahkan keadaan kehidupan rumah tangganya.

Pada penelitian yang telah dilakukan oleh Rohmah (2013), hasil penelitian menunjukkan perilaku sosial wanita mantan pelacur dalam kehidupan berumah tangga antara lain adalah: tidak banyak menuntut pada suami, bisa menikmati dan menerima hidup apa adanya, mampu mengendalikan diri/tidak cepat emosi, meninggalkan narkoba, mengikuti majlis taklim, perhatian dan kasih sayang kepada suami dan anak, saling pengertian, selalu memaafkan, saling hormat dan jujur, tidak memperberat suatu masalah, menyadari kelemahan dan kelebihan masing-masing, cuek dengan orang lain atau lingkungan yang terkadang menghina atau 
menyudutkannya, Ibadah makin tekun.

Berdasarkan penelitian Sofianti (2016), pada sisi lain seseorang wanita mantan pelacur atau mantan PSK tidak ubahnya sama dengan manusia pada umumnya, mereka juga mempunyai keinginan untuk berumah tangga atau berkeluarga bahagia secara normal. Proses penemuan suatu cita-cita ini bukanlah suatu perjalanan yang mudah bagi seseorang mantan PSK, perjalanan untuk dapat menemukan tujuan apa yang mereka berikan dalam hidup mereka. Adapun mantan PSK di eks lokalisasi di Kampung Rawa Laut Kelurahan Panjang Selatan ini yang mampu menyesuaikan diri terhadap masyarakat karena masyarakat sekitar eks lokalisasi memandang bahwa para PSK itu sendiri tidak memahami kenapa jalan itu yang harus mereka pilih. Pelacur juga manusia, mereka punya hati bahkan ada juga pelacur yang lebih baik dari pada orang yang mencemoohnya. Meskipun ada sebagian masyarakat yang menghormati mantan PSK, namun masyarakat sekitar enggan bergaul dengan mantan PSK dan lebih memilih membatasi diri dengan mereka. Maka dari itu mantan PSK itu harus dapat membuktikan dia ingin benarbenar berubah dan bertaubat sebagai manusia lainnya hidup berkeluarga seperti sebelum dia menjadi seorang PSK.

Menurut Walgito, (Dalam Afiatin, 2017) perkawinan adalah bersatunya dua orang sebagai suami istri. Perkawinan merupakan suatu ikatan janji setia lahir batin antara seorang pria dengan seorang wanita sebagai suami istri dengan tujuan membentuk keluarga atau rumah tangga yang bahagia dan kekal berdasarkan Ketuhanan Yang Maha Esa yang di dalamnya terdapat suatu tanggung jawab dari kedua belah pihak. Perkawinan merupakan komitmen emosional dan legal dari dua orang yang berbagi keintiman emosional dan fisik berbagi tugas, sumber-sumber ekonomi (Olson, Defrain \& Skogrand. dalam Afiatin 2017).

Dalam penelitian Rohim (2010), Stigma masyarakat yang negatif terhadap wanita mantan pelacur, menghambat kebutuhan bersosialisasi dengan orang lain karena subjek merasa terkucilkan di tengah kehidupan masyarakat. Keadaan tersebut diperparah dengan rasa rendah diri yang dimiliki membuat kesulitan dalam beradaptasi di masyarakat. Rasa rendah diri tersebut mencakup segala rasa kurang berharga yang timbul karena ketidakmampuan secara psikologis maupun secara 
sosial. Mantan pelacur oleh sebagian masyarakat dianggap orang yang memiliki cacat secara sosial, tetapi subjek memiliki kecenderungan untuk berusaha berinteraksi dengan lingkungan tempat tinggalnya.

Hal tersebut sesuai dengan hasil wawancara dengan informan SM yang mengatakan:

"Ketika saya memutuskan untuk berhenti menjadi psk para tetangga suami saya banyak yang bergunjing atau bergosip tentang saya, pada saat itu belum dinikahi oleh suami tetapi saya sering diajak suami berkunjung kerumah ibunya. Awal mula saya sangat ditolak oleh ibu mertua saya karena latar belakang saya yang buruk menurutnya. Orang-orang sekitar atau tetangga saya sangat mengetahui pekerjaan saya awalnya, karena tempat saya bekerja (tempat lokalisasi) sebagai psk dipinngir jalan dekat pasar daerah rumah suami saya." (Wawancara dengan SM, 45 tahun, tanggal 12 oktober 2019)

Hasil wawancara tersebut membuktikan bahwa motif pernikahan didasarkan atas dasar cinta dan untuk menuju kearah kebaikan bagi kehidupan kedua belah pihak yaitu pasutri ND dan SM. kualitas perkawinan akan memberikan pengaruh penting baik bagi individu, keluarga, masyarakat, dan bangsa. Hasil penelitian Wahyuningsih, (Dalam Afiatin, 2017), di Indonesia ditemukan bahwa faktor-faktor penting yang memengaruhi kualitas perkawinan yaitu religiusitas, komitmen perkawinan, dan pengorbanan. Komitmen perkawinan adalah niat yang kuat untuk mempertahankan atau senantiasa meneruskan hubungan perkawinan.

Sternberg (Dalam Wisnuwardhani, 2011) mengkonseptualisasikan mengenai hubungan cinta yang menyatakan bahwa cinta mencakup tiga aspek dasar, yaitu keintiman (intimacy), gairah (passion), dan komitmen (commitment). Ketiga aspek tersebut diyakini berkaitan erat dengan kepuasan pernikahan. Sebagaimana hasil penelitian yang dilakukan oleh Hoesni, dkk, (2016) bahwa terdapat hubungan yang signifikan antara semua aspek cinta (keintiman, gairah, dan komitmen) dan kepuasan pernikahan. Cinta sempurna atau Consummate Love adalah pengalaman cinta tertinggi, yang mengkombinasikan semua aspek intimasi, gairah, dan komitmen. Ketiga komponen terpenuhi dengan derajat yang seimbang. Kondisi ini dinamakan "complete". Hal ini merupakan tipe cinta yang selalu dicari oleh semua orang, namun "complete" agak sulit untuk dicapai oleh pasangan. Stenberg, (Dalam Wisnuwardhani, 2011). 
Berdasarkan pemaparan diatas, penulis tertarik untuk meneliti consummate love (cinta sempurna) pada pasutri dengan status istri mantan PSK dan usia pernikahan kurang lebih 10 tahun, karena pada penelitian yang telah dilakukan oleh Glenn (dalam Halford, Lizzio, Wilson \& Occhipinti, 2007) dalam penelitiannya mengatakan bahwa kepuasan dalam hubungan pada pasangan suami istri umumnya meningkat saat pernikahan, akan tetapi hal tersebut akan menurun dan sekitar 3-4 persen terjadi perceraian pada saat pernikahan memasuki usia 10 tahun.

Berdasarkan penjelasan diatas, maka penulis tertarik untuk melakukan penelitian dengan judul "Consummate Love Pada Pasutri Dengan Istri Mantan Pekerja Seks Komersial” penelitian ini di lakukan di Pamekasan dengan menyoroti aspek Consummate Love pada Pasutri dengan Istri Mantan PSK.

\section{Metode}

Desain Penelitian. Metode penelitian yang digunakan untuk penelitian ini adalah metode penelitian kualitatif, adapun pendekatan penelitian yang digunakan dalam penelitian ini adalah pendekatan studi kasus yang bertujuan untuk mengembangkan metode kerja yang lebih efisien.

Partisipan. Pada penelitian ini kasus yang akan diteliti merupakan kehidupan pernikahan rumah tangga pasangan suami istri dengan status istri mantan pekerja seks komersil, istri yang dahulunya pernah berkeja sebagai PSK tetapi memilih memutuskan untuk berhenti dari pekerjaannya karena adanya ikatan pernikahan.

Strategi Pengumpulan Data. Dalam penelitian ini wawacara amat diperlukan karena banyak hal yang tidak mungkin dapat diobservasi langsung, seperti perasaan, pikiran, motif, serta pengalaman masa lalu responden atau informan. Peneliti tidak hanya mewawancarai satu partisipan melainkan juga wawancara pada significant others.

Analisis Data. Menurut Yin (2015) terdapat beberapa teknik analisis data dalam penelitian studi kasus, yakni penjodohan pola, pembuatan eksplanasi, analisis deret 
waktu, analisis unit terjalin, observasi berulang, dan analisis sekunder lintas kasus. Pada penelitian kali ini peneliti menggunakan teknik analisis pembuatan eksplanasi.

Hasil Penelitian

Tabel 4.6 Hasil Tema Perbedaan Subjek I, II, III

\begin{tabular}{|c|c|c|c|c|c|}
\hline \multirow[t]{2}{*}{ NO. } & \multirow{2}{*}{$\begin{array}{c}\text { TEMA YANG } \\
\text { DIMUNCULKAN }\end{array}$} & \multicolumn{4}{|c|}{ PARTISIPAN/SUBJEK } \\
\hline & & P1 (SM) & P2 (ND) & P3 (MY) & P4 (JN) \\
\hline \multicolumn{6}{|c|}{ Intimacy (Keintiman) } \\
\hline 1. & Menghargai Pasangan & $\sqrt{ }$ & $\checkmark$ & $\checkmark$ & $\sqrt{ }$ \\
\hline 2. & $\begin{array}{l}\text { Mengetahui Kehidupan } \\
\text { Pasangan }\end{array}$ & $\checkmark$ & $\checkmark$ & $\checkmark$ & $\checkmark$ \\
\hline 3. & Keyakinan Bersama Pasangan & $\sqrt{ }$ & $\checkmark$ & $\checkmark$ & $\sqrt{ }$ \\
\hline 4. & $\begin{array}{l}\text { Kesabaran Dalam } \\
\text { Menghadapi Pasangan }\end{array}$ & & $\checkmark$ & $\checkmark$ & \\
\hline 5. & $\begin{array}{l}\text { Rasa Empati Terhadap } \\
\text { Pasangan (Kasihan) }\end{array}$ & & $\checkmark$ & $\checkmark$ & $\checkmark$ \\
\hline 6. & Mengalah & & $\checkmark$ & $\checkmark$ & $\sqrt{ }$ \\
\hline 7. & Menerima Keadaan Pasangan & $\sqrt{ }$ & $\checkmark$ & $\checkmark$ & $\sqrt{ }$ \\
\hline 8. & Kebaikan antar pasangan & $\checkmark$ & $\checkmark$ & $\checkmark$ & $\sqrt{ }$ \\
\hline 9. & Percaya kepada pasangan & $\sqrt{ }$ & $\checkmark$ & $\checkmark$ & $\checkmark$ \\
\hline \multicolumn{6}{|c|}{ PASSION (GAIRAH) } \\
\hline 1. & Komunikasi Yang Intens & $\sqrt{ }$ & $\checkmark$ & $\checkmark$ & $\checkmark$ \\
\hline 2. & $\begin{array}{l}\text { Kehadiran Pasangan ketika } \\
\text { menghadapi masalah }\end{array}$ & $\checkmark$ & $\checkmark$ & $\checkmark$ & $\checkmark$ \\
\hline 3. & $\begin{array}{l}\text { Keterbukaan (komunikasi) } \\
\text { Masalah Seksual }\end{array}$ & $\checkmark$ & & $\checkmark$ & $\checkmark$ \\
\hline 4. & Perbedaan Harapan Seksual & & & & \\
\hline 5. & Menerima Masalah Seksual & $\sqrt{ }$ & $\sqrt{ }$ & $\checkmark$ & $\sqrt{ }$ \\
\hline 6. & Percaya Terhadap Pasangan & & $\checkmark$ & $\checkmark$ & $\checkmark$ \\
\hline 7. & $\begin{array}{l}\text { Siap Menerima Keadaan } \\
\text { Pasangan }\end{array}$ & $\checkmark$ & $\checkmark$ & $\checkmark$ & $\checkmark$ \\
\hline 8. & Daya Tarik Fisik & & & $\checkmark$ & $\checkmark$ \\
\hline 9. & $\begin{array}{l}\text { Kesehatan dalam hubungan } \\
\text { seksual antar pasangan }\end{array}$ & $\sqrt{ }$ & $\checkmark$ & $\sqrt{ }$ & $\checkmark$ \\
\hline 10. & $\begin{array}{l}\text { Tidak menuntut pasangan } \\
\text { dalam kehidupan seksual }\end{array}$ & $\checkmark$ & $\checkmark$ & $\checkmark$ & $\checkmark$ \\
\hline 11. & $\begin{array}{l}\text { Tidak memaksa memenuhi } \\
\text { kekurangan dalam kehidupan } \\
\text { rumah tangga }\end{array}$ & $\checkmark$ & $\checkmark$ & $\checkmark$ & $\checkmark$ \\
\hline 12. & $\begin{array}{l}\text { Kecocokan sifat yang saling } \\
\text { melengkapi pasangan }\end{array}$ & $\checkmark$ & $\checkmark$ & $\checkmark$ & $\checkmark$ \\
\hline \multicolumn{6}{|c|}{ COMMITMENT (KOMITMEN) } \\
\hline 1. & $\begin{array}{l}\text { Usaha Mempertahankan } \\
\text { Rumah Tangga }\end{array}$ & $\checkmark$ & $\checkmark$ & $\checkmark$ & $\checkmark$ \\
\hline
\end{tabular}




\begin{tabular}{|c|l|c|c|c|c|}
\hline NO. & \multicolumn{1}{|c|}{ TEMA YANG } & \multicolumn{3}{|c|}{ PARTISIPAN/SUBJEK } \\
\hline & \multicolumn{1}{|c|}{ DIMUNCULKAN } & P1 (SM) & P2 (ND) & P3 (MY) & P4 (JN) \\
\hline 2. & $\begin{array}{l}\text { Meyakini Ketepatan Dalam } \\
\text { Memilih Pasangan }\end{array}$ & $\checkmark$ & $\checkmark$ & $\checkmark$ & $\checkmark$ \\
\hline 3. & $\begin{array}{l}\text { Tidak Ingin Kembali kepada } \\
\text { Masalalu (PSK) }\end{array}$ & $\checkmark$ & $\checkmark$ & $\checkmark$ & $\checkmark$ \\
\hline 4. & Menjalani Komitmen & $\checkmark$ & $\checkmark$ & $\checkmark$ & $\checkmark$ \\
\hline 5. & $\begin{array}{l}\text { Bahagia Dalam kehidupan } \\
\text { Rumah Tangga }\end{array}$ & $\checkmark$ & $\checkmark$ & $\checkmark$ & $\checkmark$ \\
\hline 6. & $\begin{array}{l}\text { Rasa Bersyukur Dalam } \\
\text { Kehidupan Rumah Tangga } \\
\text { Saat ini }\end{array}$ & $\checkmark$ & $\checkmark$ & $\checkmark$ & $\checkmark$ \\
\hline 7. & $\begin{array}{l}\text { Meyakini kehidupan saat ini } \\
\text { lebih baik untuk sesama } \\
\text { pasangan }\end{array}$ & $\checkmark$ & $\checkmark$ & $\checkmark$ & $\checkmark$ \\
\hline 8. & $\begin{array}{l}\text { Berpengaruhnya komitmen } \\
\text { terhadap keharmonisan rumah } \\
\text { tangga }\end{array}$ & $\checkmark$ & $\checkmark$ & $\checkmark$ & $\checkmark$ \\
\hline 9. & $\begin{array}{l}\text { Sabar dan ikhlas dalam } \\
\text { menghadapi masalah rumah } \\
\text { tangga }\end{array}$ & $\checkmark$ & $\checkmark$ & $\checkmark$ & $\checkmark$ \\
\hline 10. & $\begin{array}{l}\text { Tidak peduli pendapat } \\
\text { orangtua }\end{array}$ & & & & \\
\hline 11. & $\begin{array}{l}\text { Mengingat dan meyakini } \\
\text { kebaikan pasangan }\end{array}$ & $\checkmark$ & $\checkmark$ & $\checkmark$ & $\checkmark$ \\
\hline 12. & $\begin{array}{l}\text { Tujuan menikah untuk hidup } \\
\text { yang lebih baik }\end{array}$ & $\checkmark$ & $\checkmark$ & $\checkmark$ & $\checkmark$ \\
\hline 13. & $\begin{array}{l}\text { Tidak mau berpisah dengan } \\
\text { pasangan dengan resiko yang } \\
\text { terjadi } \\
\text { menghadapi permasalahan } \\
\text { mencukupi kebutuhan batin } \\
\text { antar pasangan) }\end{array}$ & $\checkmark$ & $\checkmark$ & $\checkmark$ & $\checkmark$ \\
\hline 15. & $\begin{array}{l}\text { Keinginan untuk membuat } \\
\text { pasangan hidup bahagia }\end{array}$ & $\checkmark$ & $\checkmark$ & $\checkmark$ & $\checkmark$ \\
\hline
\end{tabular}

Menurut Pada hasil yang telah didaptkan triangulasi sumber dapat disimpulkan bahwa ada sedikit perbedaan hasil tema dari setiap aspek consummate love yang artinya ada kemungkinan kedua pasutri sering mengalami konflik-konflik ringan dalam rumah tangganya. Namun dengan penyelesaian konflik pada kedua pasutri tersebut tidak lepas dari adanya komunikasi dan pengertian dari kedua belah 
pihak pasangan untuk mendukung terjalannya consummate love dengan tantangan konflik tersendiri bagi masing-masing pasutri.

\section{Pembahasan}

Intimacy atau keintiman pada pasutri SM dan ND dari hasil wawancara dapat ditarik kesimpulan bahwa keduanya melengkapi kekurangan pasangan diawal pertemuan dengan cara komunikasi dan pertemuan yang intens sehingga, SM dan ND bisa saling memahami untuk terus menjalinnya sebuah hubungan pernikahan. Dengan keyakinan yang telah dimiliki bahwa pasangan bisa menjadi partner seumur hidupnya. Menghargai pasangan, mengetahui kehidupan pasangan, komunikasi yang intens, seringnya bertemu, sopan terhadap pasangan, keyakinan bersama pasangan, saling mengalah, kesabaran menghadapi pasangan, mengerti dan memahami keadaan pasangan, hal-hal tersebut yang dilakukan oleh pasutri SM dan ND hingga saat ini dalam kehidupan rumah tangganya.

Intimacy atau keintiman pada pasutri MY dan JN dari hasil wawancara, yaitu meyakini pasangan orang yang baik untuk sesama pasangan, sama-sama memiliki sifat yang tegas untuk menghadapi permasalahan dalam hubungan pasangan, bisa menerima apa adanya keadaan pasangan disaat sakit maupun sehat, rasa empati (kasihan) terhadap sesama pasangan, percaya sepenuhnya terhadap pasangan, merupakan hal yang terus diperhatikan dan dilakukan oleh pasutri MY dan JN hingga saat ini. Tidak hanya pada awal dimulainya sebuah hubungan sepasang kekasih dan sepasang suami istri hal-hal tersebut menurut kedua pasutri harus dilakukan seterusnya untuk membangun sebuah hubungan rumah tangga yang sejahtera bagi subjek kedua pasutri SM dan ND begitu juga MY dan JN dalam memaknai sebuah hubungan pasangan suami istri.

Passion atau gairah pada pasutri MY dan JN mengakui bahwa keduanya tertarik kepada pasangan dikarenakan adanya daya tarik fisik secara nyata, dan mengagumi terpesona kepada pasangan, akan tetapi keadaan saat ini bagi pasangan MY dan JN sangatlah berbeda dengan pertemuan awal mereka dapat dikatakan bahwa JN saat ini tidak bisa memenuhi kebutuhan hubungan seksual suami istri dengan kondisinya yang mengalami sakit stroke ringan, hal tersebut lantas tidak 
menjadi permasalahan bagi MY sebagai istrinya, menurutnya kesembuhan dan perawatan JN saat ini menjadikan hal utama untuk bisa dilakukannya sebaik mungkin, karena menurut MY suaminya sangat berarti dikehidupannya sejauh ini.

Lain halnya dengan subjek SM dan ND yang dapat disimpulkan bahwa keduanya tertarik karena memang rasa empati kepada pasangan SM dan rela melakukan sesuatu demi pasangannya. Komunikasi yang intens dan seringnya bertemu untuk membicarakan permasalahan satu sama lain menjadikan hubungan kedua pasutri tersebut semakin dekat dan bisa memahami satu sama lain dengan tujuan bersama untuk mengubah hidup lebih baik lagi.

Dapat disimpulkan bahwa passion atau gairah pada pasutri tersebut dapat berubah sesuai kondisi waktu yang dialami, tetapi tidak menjadikannya alasan untuk tidak harmonisnya kehidupan dalam rumah tangga, menerima dan saling melengkapi sangat dibuthkan untuk terus terjalinnya rumah tangga yang bahagia.

Dan dari aspek commitment yakni, Usaha Mempertahankan Rumah Tangga, Meyakini Ketepatan Dalam Memilih Pasangan, Tidak Ingin Kembali kepada Masalalu (PSK), Menjalani Komitmen, Bahagia Dalam kehidupan Rumah Tangga, Rasa Bersyukur Dalam Kehidupan Rumah Tangga Saat ini, Meyakini kehidupan saat ini lebih baik untuk sesama pasangan, Berpengaruhnya komitmen terhadap keharmonisan rumah tangga, Sabar dan ikhlas dalam menghadapi masalah rumah tangga, Tidak peduli pendapat orang tua, Mengingat dan meyakini kebaikan pasangan, Tujuan menikah untuk hidup yang lebih baik, Tidak mau berpisah dengan pasangan dengan resiko yang terjadi, Menguatkan pasangan untuk menghadapi permasalahan yang ada (memberi motivasi, mencukupi kebutuhan batin antar pasangan), Keinginan untuk membuat pasangan hidup bahagia. Faktorfaktor tersebut menunjukkan hasil dari wawancara ke 4 subjek dengan berpedoman pada aspek consummate love yang terdiri dari intimacy, passion dan commitment. 


\section{Kesimpulan}

Korelasi Kesimpulan yang dapat diambil pada penggambaran consummate love melalui aspek intimacy (keintiman) milik Sternberg ini diketahui bahwa, pasutri terjalin dengan adanya keterbukaan kedua belah pihak suami dan istri ketika awal pendekatan maupun sesudah adanya ikatan pernikahan. Kesadaran satu sama lain akan adanya pasangan yang selalu di butuhkan dan selalu ada jika dibutuhkan memberikan kontribusi penting dalam menjalakan rumah tangga. Dapat disimpulkan bahwa passion atau gairah pada kedua pasutri tersebut bisa berubah sesuai kondisi waktu yang dialami, tetapi tidak menjadikannya alasan untuk tidak harmonisnya kehidupan dalam rumah tangga, menerima dan saling melengkapi sangat dibuthkan untuk terus terjalinnya rumah tangga yang bahagia. Sulit mudahnya mewujudkan dan mempertahankan cinta sejati atau cinta sempurna bergantung pada hubugan itu sendiri dan dukungan situasi terhadapnya. Consummate love atau cinta sempurna seperti barang berharga lainnya, harus dijaga dengan baik. Di iringi keterlibatan emosional yang mendalam sebagai bentuk komponen keintiman, pemenuhan kebutuhan motivasional, seperti pengasuhan, penghargaan diri, aktualisasi diri yang ditemukan pada komponen hasrat dan komitmen nyata, yang merupakan bentuk dari komponen keputusan atau komitmen.

Berdasarkan pembahasan yang telah dilakukan oleh peneliti maka saran yang dapat diberikan peneliti adalah sebagai berikut:

a. Bagi hubjek hasil penelitian ini diharapkan dapat menambah pengetahuan ketika subjek pasangan suami istri memiliki cinta sempurna dalam kehidupan pernikahannya akan lebih termotivasi dan tetap bertahan dalam menjalankan hubungan pernikahan yang bahagia, meskipun dengan status masalalu istri sebagai mantan pekerja seks komersial, tidak adanya anak dalam rumah tangganya dan rendahnya keadaan ekonomi keluarga. Adanya konflik yang terjadi pada rumah tangga bisa menjadikan sumber pemahaman dan pelajaran baru dengan memperhatikan komunikasi intimacy, passion dan commitment bagi pasutri untuk memperbaiki tujuan kehidupan dalam rumah tangga. Consummate love atau cinta sempurna seperti barang berharga lainnya, harus dijaga dengan baik. 
b. Bagi keluarga hasil penelitian ini diharapkan menambah motivasi bagi keluarga dari suami (mertua, sanak saudara suami) untuk tetap mendukung pernikahannya dengan tidak mempermasalahkan masa lalu istrinya sebagai mantan pekerja seks komersial dan saling menghargai antara anak dan menantu dalam kehidupan rumah tangganya.

c. Bagi masyarakat hasil penelitian ini diharapkan memberi pengetahuan baru bahwa wanita mantan pekerja seks komersial yang berumah tangga memiliki sisi positif juga dalam hubungan pernikahan, masyarakat dapat saling menghargai kepada semua rumah tangga ataupun pasutri dengan berperilaku baik sesuai dengan nilai budaya dan agama. Dapat memotivasi bagi pasangan pasutri lainnya, untuk bisa bersikap berusaha menyempurnakan, saling melengkapi kehidupan pernikahan menuju cinta sempurna pasutri keluarga bahagia, dan tercapainya keharmonisan juga kepuasan pernikahan yang diinginkan oleh setiap pasutri.

d. Bagi Peneliti Selanjutnya Hasil penelitian ini diharapkan bisa menjadi bahan refrensi tentang consummate love bagi peneliti selanjutnya, hingga mempermudah saat melakukan penelitian baik dalam variabel atau fenomena kasus yang sama. Peneliti juga mengharapkan bahwa peneliti selanjutnya dapat melakukan penelitian yang lebih mendalam terkait permasalahan yang sama tetapi dengan subjek yang berbeda, agar dapat dijadikan refrensi baru ataupun pendukung untuk informasi mengenai consummate love pada pasutri dengan istri mantan pekerja seks komersial.

\section{Daftar Pustaka}

Afiatin, Tina. (2017). Psikologi Perkawinan dan Keluarga. Yogyakarta: PT Kanisius.

Aryani, Rosita. (2016). Hubungan Komponen Cinta Dengan Kepuasan Berpacaran Pada Dewasa Awal. Vol.5 No.1. Fakultas Psikologi Universitas Surabaya.

Deddy, Mulyana. (2010). Metodologi Penelitian Kualitatif. Bandung: PT. Remaja Rosdakarya. 
Durotunnasa, Nisrina. (2017). Kepuasan Pernikahan Pada Pasangan Dengan Latar Belakang Suku Yang Berbeda. Skripsi. Surakarta: Universitas Muhammadiyah Surakarta.

Erwinda, Lira. (2016). Urgensi Intimacy Dalam Kehidupan Berkeluarga Pasangan Dewasa Awal. Volume 2 Nomor 2. Universitas Negeri Padang.

Fitri, Sandrina. (2019). Hubungan antara Gaya Kelekatan Cinta dan Cinta Sempurna dengan Kepuasan Pernikahan Pada Pasangan Yang di Jodohkan di Pesantren Hidayahtullah Kalimantan Timur. Volume. 7, Nomor 1. Kalimantan Timur: Universitas Mulawarman.

Hurlock, E,B. 2004. Psikologi Perkembangan. Jakarta: Erlanggga.

Moleong, L. J. (2014). Metode Penelitian Kualitatif Edisi Revisi. Bandung: Remaja Rodaskarya.

Kartono, Kartini. (2017). Patologi Sosial Jilid 1. Depok : PT Raja Grafindo Perseda.

Kartono, Kartini. (2014). Patologi Sosial 3. Jakarta : PT Raja Grafindo Perseda.

Kartono, Kartini. (2009). Psikologi Abnrmal \& Abnormalitas Seksual. Bandung : CV Mandar Maju.

Latifatunnikmah \& Sri Lestari. (2017). Komitmen Pernikahan Pada Pasangan Suami Istri Bekerja. Vol 14, No.2. Fakultas Psikologi Universitas Muhammadiyah Surakarta.

Matondang, Armansyah. (2014). Faktor-Faktor Yang Mengakibatkan Perceraian Dalam Perkawinan. Universitas Medan Area, Indonesia.

Nangsih, Ratna. (2013). Kehidupan Mantan Pekerja Seks Komersil (PSK). Skripsi. Yogyakarta: Universitas Negeri Yogyakarta.

Putri, D.K \& Hamidah. (2018). Gambaran Makna Hidup Pada Perempuan Usia Dewasa Awal Mantan Pekerja Seks Komersial (PSK) Binaan Yayasan Gerakan Melukis Harapan. Jurnal Psikologi Klinis dan Kesehatan Mental. Volume. 7, PP.1-11. Departemen Psikologi Klinis dan Kesehatan Mental : Fakultas Psikologi Universitas Airlangga.

Retnaningtyas, Frut.D. (2007). Komponen Cinta Pada Individu Yang Telah Menikah Menurut Triangular Theory Of Love. Skripsi. Yogyakarta : Universitas Sanata Dharma Yogyakarta. 
Rohim, Syaiful. (2010). Konsep Diri Eks Wanita Tuna Susila di Panti Sosial. Volume. 8, Nomor 1. Jakarta Selatan : Universitas Profesor Muhammad Hamka Jakarta.

Rohmah, Noer. (2013). Keluarga Sakinah Wanita Mantan Pelacur. (Study Life History). Vol. 04, No. 01.

Saraswati, Putri. (2011). Hubungan Antara Persepsi Anak Terhadap Peran Orangtua Dalam Pemilihan Pasangan Hidup Dengan Kecenderungan Pemilihan Pasangan Hidup Berdasarkan Status Sosial Ekonomi Pada Dewasa Awal. Surabaya: Jurnal Psikologi, Universitas Airlangga.

Setiawan, Yamin. (2014). Kesempurnaan Cinta dan Tipe Kepribadian Kode Warna. Vol. 3, No. 01, hal 90-96. Surabaya : Universitas 17 Agustus 1945.

Simandjuntak, B. (1981). Pengantar Kriminologi \& Patologi Sosial. Bandung : Tarsito.

Sofianti, Evalita. (2016). Persepsi Masyarakat Terhadap Mantan PSK (Pekerja Seks Komersial) Yang Telah Berkeluarga (Study di Kampung Rawa Laut Kelurahan Panjang Selatan Kota Bandar Lampung). Skripsi. Bandar Lampung :Universitas Lampung.

Sternberg, Robert J. (2009). Cupids Arrow Panah Asmara Konsepsi Cinta dari Zaman ke Zaman. Yogyakarta : Pustaka Pelajar.

Toha, Mohammad Maimun \& Arifin, Misbahul. (2018). Fenomena Tingginya Angka Cerai- Gugat dan Faktor Penyebabnya: Analisis Reflektif Atas Kasus Perceraian Di Madura. Volume 5 Nomor 2. Institut Agama Islam Negeri (IAIN) Madura.

Wisnuwardhani, Dian \& Mashoedi, Sri Fatma. (2011). Hubungan Interpersonal. Jakarta : Salemba Humanika.

W, N. Adinda Destiani. (2008). Penerimaan Diri Mantan PSK. Skripsi. Surakarta : Fakultas Psikologi. Universitas Muhammadiyah Surakarta.

Yin, Robert K. (2019). Studi Kasus Desain \& Metode. Depok : PT Rajagrafindo Persada. 